\title{
INVESTIGATING THE CRITICAL SUCCESS FACTORS FOR WATER SUPPLY PROJECTS: CASE OF IRAQ
}

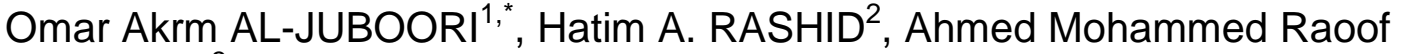 \\ $\mathrm{MAHJOOB}^{3}$ \\ ${ }^{1}$ University of Baghdad, College of Science, Reconstruction and Projects Unite, Baghdad, Iraq. \\ ${ }^{2}$ College of Engineering, Department of Civil Engineering, Al-Nahrain University, Iraq. \\ ${ }^{3}$ University of Baghdad, College of Engineering, Civil Engineering Department, Baghdad, Iraq. \\ * corresponding author: omar.a@sc.uobaghdad.edu.iq
}

\begin{abstract}
Water supply projects (WSP) requires high plan information, specialized capabilities, capable human resources, and high administrative capacity. However, in the developing countries, particularly in Iraq, these projects experience a lack of a large number of these necessities, which shows the need to identify the critical success factors (CSFs). Accordingly, the objectives of this research are to investigate the CSFs for WSP and their significance among the construction (public and private) and education sectors. To achieve this, first we have carried out a comprehensive literature review of the CSFs for WSP. Second, we administrated a questionnaire survey to 260 construction experts working in the construction and education sectors. It was found that the top five important success factors for water supply projects in Iraq were a stable political environment; sustainable construction legislation and regulation; effective risk management practices; well-organized and committed project teams; and government decisions through the project life cycle. The survey results did not indicate major differences in the perception of the experts. The findings are focused to assist construction practitioners' gain better understanding on the important areas to achieve project set objectives.
\end{abstract}

\author{
Keywords: \\ Critical Success Factors (CSFs); \\ Construction projects; \\ Water supply projects; \\ Infrastructure development; \\ Iraq projects.
}

\section{Introduction}

Based on the Organisation for Economic Co-operation and Development (OECD), the world population has expanded four times through the twentieth century. Consequently, water utilization has grown sevenfold. Moreover, the proportion of the total populace living in water-stressed nations is expected to develop from presently $33 \%$ to $66 \%$ by 2025 [1]. Infrastructure projects such as water supply systems, highways, tunnels, airports, and power plants are characterized as large-scale projects and a complex venture that takes many years to develop. These projects connect multiple public and private stakeholders and have a direct impact on millions of people [2]. Existing infrastructures are one of the most important differential aspects of developing countries. The critical factors of success (CSF) in water supply projects are likely to differ compared to other infrastructure projects $[3,4]$

Several scholars have studied the CSF in construction projects in general such as (Sharma [5]; Asgari et al. [6]; Gunduz and Yahya [7]; Panchal [8]; Tamgadge and Shinde [9]; Mbiti [10]; Silva et al. [11]; Osorio et al. [12]; Pakseresht and Asgari [13]; Tabish and Jha [14]; and Saqib et al. [15]. In Iraq, there is a lack of studies that investigate the CSF in water supply projects.

In addition, there is even less research regarding the causal impacts between these factors and project objectives. Moreover, the Iraqi contracting companies find a big number of challenges to effectively manage projects in an environment with poor supplies, security threats, unskilled workforce, 
and logistics difficulties. Furthermore, the Iraqi economy relies on petroleum production, and the construction industry does not have a significant impact on the economy [16].

Accordingly, the objectives of this research are to investigate the CSF for water supply projects in Iraq and their significance among the construction (public and private) and education sectors. The rest of the paper is organized as follows: Section 2 presents the material and method. Section 3 discusses the results, and finally, the conclusions and future trends in research are tackled in Section 4.

During the 1980s and 1990s, the Government of Iraq (Gol), made critical infrastructure investments; as a result; urban access to drinkable water reached $95 \%$ while it was $75 \%$ for rural areas. However, this is not the case after 2003, where the majority of infrastructure projects, specifically water supply systems, were damaged due to the ill security situation in Iraq [17]. In 2004, urban access to drinkable water fell from $95 \%$ to $73 \%$; and rural areas fell from $75 \%$ to $43 \%$, while $25 \%$ of Baghdad's people were unconnected to a water supply network [18]. Moreover, it is assessed that $40 \%-50 \%$ of Iraq's water distribution networks, measuring to $40,000 \mathrm{~km}$ of pipes and valves, require replacement due to damage, corrosion, and aging piping infrastructure. The assessed productivity of drinking water production facilities of 2018 ran somewhere in $66.7 \%$ of the design capacity [19].

Recently, as shown in Fig. 1, in the year 2018, residential construction projects were the biggest market in the construction industry with $42.6 \%$ of the Iraqi industry's total value, which reflects the considerable need for water supply projects to meet the market demand. Furthermore, infrastructure construction accounted for $37.15 \%$ of the industry's total output, commercial construction with $10.5 \%$, industrial construction with $6.3 \%$, and institutional construction with $3.5 \%$.

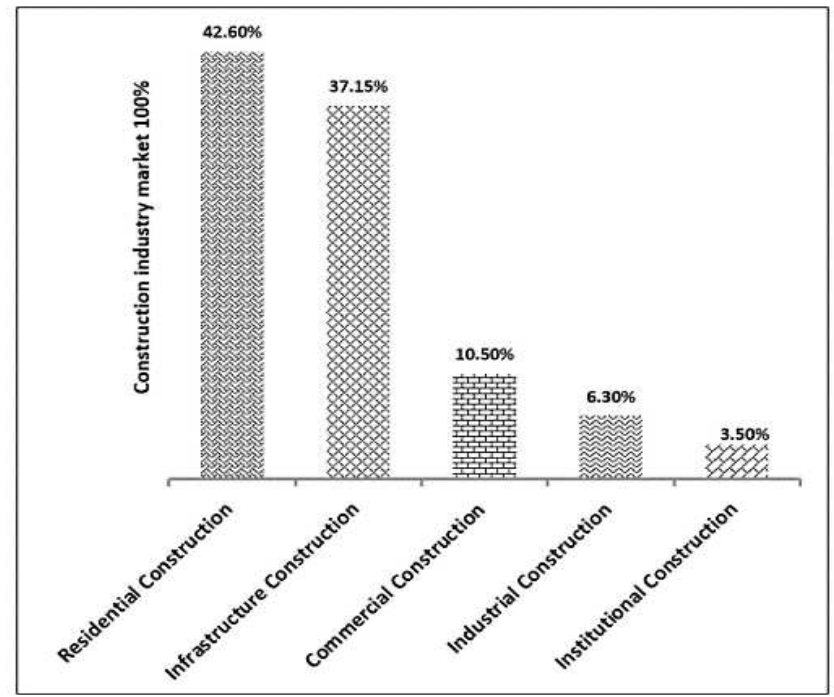

Fig. 1: Iraqi industry's total value in 2018 [20].

Generally, the provision of water supply services in Iraq is managed by three organizations, namely: Ministry of Municipalities and Public Works of Kurdistan region; Ministry of Municipalities and Public Works; and the Municipality of Baghdad by Baghdad Water Directorate. In 2018, as the Iraqi population reached 39 million, the Gol declared policies to invest over US $\$ 100$ billion by 2027 to reconstruct the damaged infrastructure, particularly the water supply systems. Additionally, in 2018, the Gol launched the National Development Plan, in which it aims to increase the served people percentage to $97 \%$ in Baghdad and $72.66 \%$ in other governorates [20], which reflects again the need for new water supply projects.

Water supply project require high plan information, specialized capabilities, capable human resources, and high administrative capacity. However, in the developing countries, particularly in Iraq, these projects experience a lack of a large number of these necessities, which shows the need to identify a list of CSFs. Critical success factors are defined by Patanakul and Milosevic [21] as characteristics, conditions, or variables that can have a significant impact on the success of the project when properly sustained, maintained, or managed. They are those elements which, if not paid attention to, might prompt the disappointment of a project task. Understanding these factors helps guide the endeavors and resources of such projects, especially in high populated regions [22]. 
Several scholars have investigated the CSFs for construction projects. For example, Nguyen et al. [23], in their study, they recognized the five top CSFs factors for project success in large construction projects in Vietnam, these factors were competent project manager; providing adequate financial resources to the end of the project; competent and multidisciplinary project team; commitment to the project; and access to resources. Moreover, Saqib et al. [15] identified 77 CSF in 7 different construction projects in Pakistan, the top five factors were: decision making effectiveness; project manager's experience; contractor's cash flow; contractor experience, timely decision by owner/owner's representative.

In addition, Tabish and Jha[14] evaluated the CSF for infrastructure projects in India, the study yielded four success factors, namely, awareness of and compliance with rules and regulations; preproject planning and clarity in scope; effective partnering among project participants; and external monitoring and control. Pakseresht and [13], in their study they considered the following dimensions as the CSFs in construction projects in Iran, namely, technical and economic assessment of the project required resources; experience and executive records of the project manager; project strategic planning and executive experience of the contractor team about the project subject. Osorio et al. [12] indicated through a survey research in Brazil that the support from upper management and clearly defined and detailed scope of work as the most significant success factors of construction projects. Moreover, Silva et al. [11] used the critical literature review to identify critical success factors on the project execution stage of construction projects, 40 external factors and 34 internal factors were identified. The top five external factors were: low level of government; client's financial ability, client's involvement \& monitoring; design and material changes by the client; social /cultural environment \& community involvement. While the top five internal factors were: adequate communication among all project participants; effective quality assurance program; top management support \& commitment to the project; availability of advanced /new technologies; and detailed project planning.

Furthermore, Mbiti [10] in their study, they found that the use of BIM technology; stakeholder participation and project team competency influence the effective implementation of construction projects in Kenya. Tamgadge and Shinde [9] identified the top 5 CSFs in India. Those factors were: good leadership; decision making for the project; safety at the workplace; quality of work delivered; and communication with clients/contractors.

Furthermore, Panchal [8] explored 19 key success factors in the operation and maintenance of water supply projects in India. The study found that the most significant success factor was the technical feasibility and reliability and the least significant factor was the political and social support. Gunduz and Yahya [7] identified 25 project success factors in the construction industry in UAE. As a result, the company's technical capacity and scope and work definition were ranked as the most important factors for success. Asgariet al. [6] identified the impact of CSFs in the construction industry in Iran, 41 CSFs were selected and classified into five major categories: financial, interactive processes, human resources, contractual arrangements, and project characteristics. Finally, Sharma [5] developed a conceptual framework on the CSFs in construction projects in India, through six groups of independent variables, namely: project-related factors, project management/team memberrelated factors; project manager-related factors, client-related factors, contractor-related factors, and external factors.

The scope of this research focuses on water supply projects in the Iraq. The research is limited to construction professionals represented by consultants, contractors, owners, project managers, and academics working in the construction and education sectors in Iraq.

\section{Material and methods}

A mixed-method approach was used in this study to investigate the CSFs for water supply projects in Iraq. The decision of the selected research methods depends on the study nature, purpose of the research, research objectives, the availability of resources and previous literature. The main research question of this study is: "What are the critical factors for success for water supply projects in Iraq?"

\subsection{Data collection and sampling}

Data collection occurred between August 1, 2020 and October 31, 2020. The qualitative approach is used to extract a set of project success factors based on related literature including handbooks, journal articles, conference papers, and research reports. 
Searches for relevant materials were performed using Scopus and Clarivate database. Keywords used for searching the published work included water supply projects, success factors, and construction management. The keywords were selected from previously published research, see Table 2. On the other hand, the quantitative approach was used to investigate the importance of these factors via a questionnaire survey. The questionnaire survey was first developed based on the author's construction management experience. Then, a pilot study was carried out with 10 construction experts to check the questionnaire structure and internal validity. Those experts have more than 15 years of experience and working in the public and private construction sectors in Iraq.

In this research 260 questionnaire forms were sent to construction experts working at the Ministry of Higher Education and Scientific Research, Ministry of Construction and Housing, and Municipalities and Public Works and Baghdad Municipality, Baghdad Water Directorate, and local and international construction companies working in Iraq. The Questionnaire survey consists of 2 parts. The first part is concerned about the participants experience, information, and background, while the second part focuses on the CSFs of Iraqi water supply projects. 18 factors were involved in the questionnaire allowing each participant to rate the CSFs according to 6-point Likert scale ranging from 1 for very unimportant to 6 for very important to a choice of $0=$ Do not know/ Not applicable.

\subsection{Data analysis}

The Statistical Package for Social Sciences (SPSS) v.20 software was used to undertake the statistical tests. The information gathered from the poll study was broken down utilizing the mean score strategy to set up the overall significance for success factors, where lower levels of importance were indicated a lower value.

A three-level data analysis framework was used in this research. The individual success factors were positioned at the main level in a downward order of the mean scores to distinguish the significant success factors. This demonstrates a general image about various respondents' impression on the success factor significance. At the subsequent level, the understanding of the respondents cum consistency recognition was checked and analysed by Kendall's concordance for the research groups.

Finally, both of Kruskal Wallis and Mann-Whitney $U$ tests were used to enable group's comparisons. Kruskal Wallis $\mathrm{H}$ test is a rank-based nonparametric test used to compare between two or more groups that may have different sample sizes. On the other hand, Mann-Whitney $U$ test is a nonparametric test used when the data do not meet the requirements for a parametric test (i.e., if the data are measurements on an ordinal scale).

The test was accomplished at a significance level of $5 \%$. This nonparametric test tool was used because of the imbalanced sizes of the three independent groups. Table 3 shows the determined mean scores along with comparing standard deviation and positions for every success factor as considered by the three groups of respondents.

\section{Results and discussions}

\subsection{Literature analysis}

Based on reviewing and analysing the related literatures, Table1 shows the list of critical factors for success (CSF).

Table1: List of critical success factors (CSF).

\begin{tabular}{|c|c|c|}
\hline No. & Factors & Reference \\
\hline F1 & Stable and supporting macroeconomic environments & [5], [8], [12] and [24] \\
\hline F2 & Sustainable construction legislation and regulation & {$[5],[14]$, and [24] } \\
\hline F3 & $\begin{array}{c}\text { Technical feasibility and economic assessment of the } \\
\text { project }\end{array}$ & {$[5],[6],[8],[10],[13]$ and [24] } \\
\hline F4 & Effective cost control measures & {$[5],[6],[8],[9]$, and [12] } \\
\hline F5 & Independence of regulatory institutions & {$[6],[14]$ and [24] } \\
\hline F6 & Effective risk management practices & {$[5],[6],[8],[12]$ and [24] } \\
\hline F7 & Stable political environment & {$[6],[8],[12]$, and [24] } \\
\hline F8 & Availability of financial resources $[23]$ and [24] \\
\hline F9 & Well organized and committed project team & {$[5],[6],[8],[9],[12],[13]$, and [24] } \\
\hline
\end{tabular}




\begin{tabular}{|c|c|c|}
\hline F10 & Effective internal and external communication & {$[6],[8],[12],[14]$ and [24] } \\
\hline F11 & Government decisions through the project life cycle & {$[9],[15]$ and [24] } \\
\hline F12 & Social acceptance & {$[5],[8]$ and [24] } \\
\hline F13 & Project profitability & {$[5],[6]$ and [8] } \\
\hline F14 & Effective supply chain operations & {$[6]$ and [12] } \\
\hline F15 & Top management support from client organization & {$[6],[6],[12]$, and [24] $[13],[23]$ and [24] } \\
\hline F16 & Availability of project resources. & {$[8]$ and [11] } \\
\hline F17 & Project management efficiency and experience & {$[5],[6],[7],[8],[10],[12],[13],[15],[23]$ and [24] } \\
\hline F18 & End user satisfaction. & \\
\hline
\end{tabular}

\subsection{Questionnaire survey}

In total, 133 out of 260 questionnaire forms were returned, in which 105 of them were completed. The effective response rate was $40.38 \%$, which deemed adequate for the purposes of data analysis. To determine the responses' reliability, Cronbach's alpha test was applied. In this questionnaire, Cronbach's alpha of 0.647 was reached, which indicates that the research questionnaire has adequate reliability. This result confirmed the appropriateness of further analysis of the data.

\subsubsection{Characteristics of respondents}

Respondents' the profile pointed out that $45.71 \%$ of them were from governmental organizations (public sector), and $27.62 \%$ of the respondents were working in private organizations (private sector), whereas $26.67 \%$ were academics (Education sector). Moreover, $56.1 \%$ of the participants had 21 years or more of experience in the construction sector. As for the educational qualifications of the respondent's profile, it was indicated that $59 \%$ of the participants had a bachelor's degree. On the other hand, PhD, MSc, and high diploma holders form $26 \%, 10 \%$, and $5 \%$, respectively.

Results indicate that most of the respondents hold official managerial positions. Consultant positions formed $26.2 \%$ of the research sample, while $16.8 \%$ of the respondents served as department directors. On the other hand, senior level and general director positions comprised $14 \%$ each. This indicates that the data received can be considered as dependable and that the majority of the respondents have the required knowledge and experience to answer the questionnaire. Table 2 describes the profile of the research respondents. Furthermore, Figs. 2 to 6 show the respondents' distribution in terms of working sector and job title.

Table 2: Profile of the respondents.

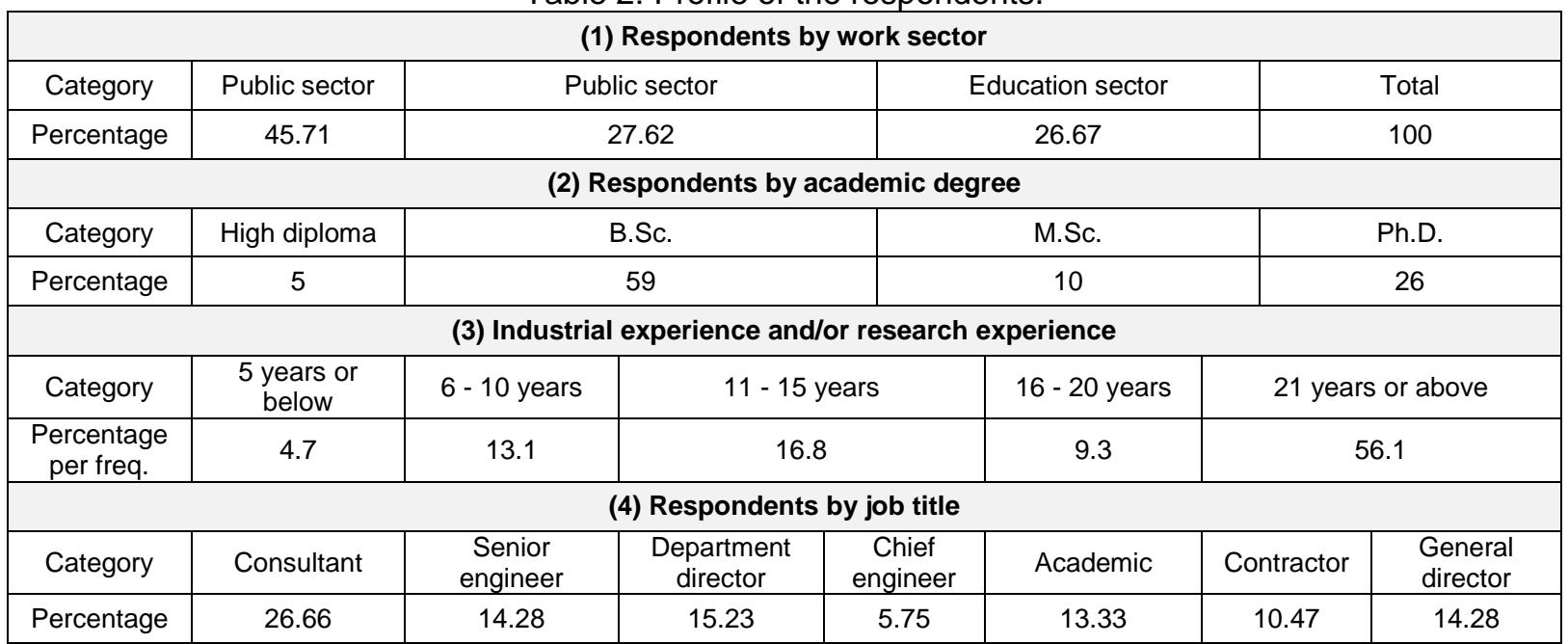




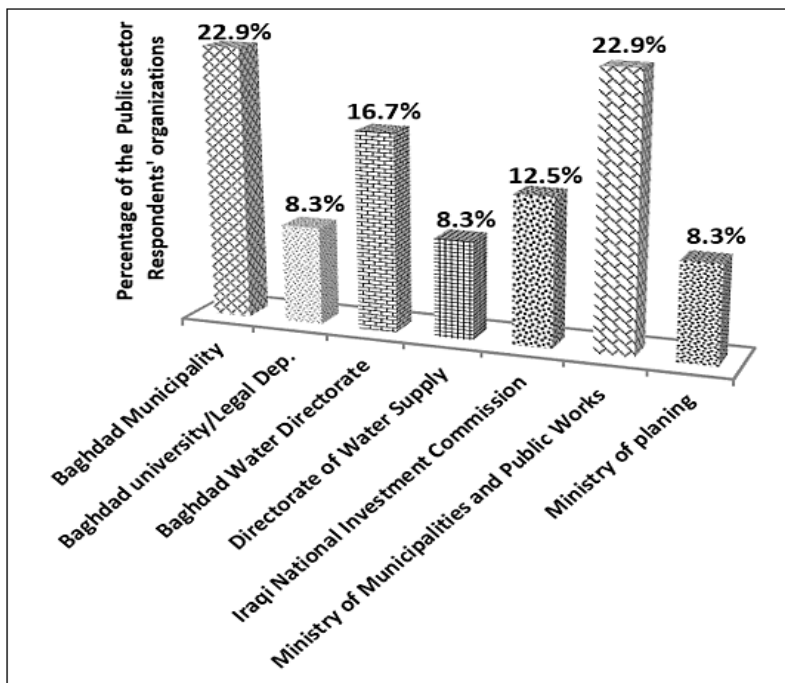

Fig. 2: The public sector respondents organizations.

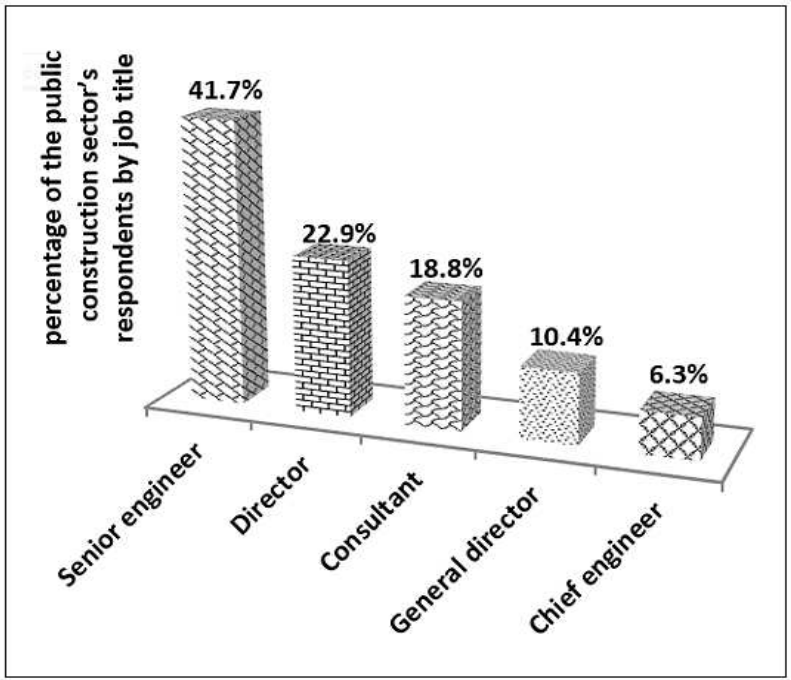

Fig. 4: The public sector respondents according to job title.

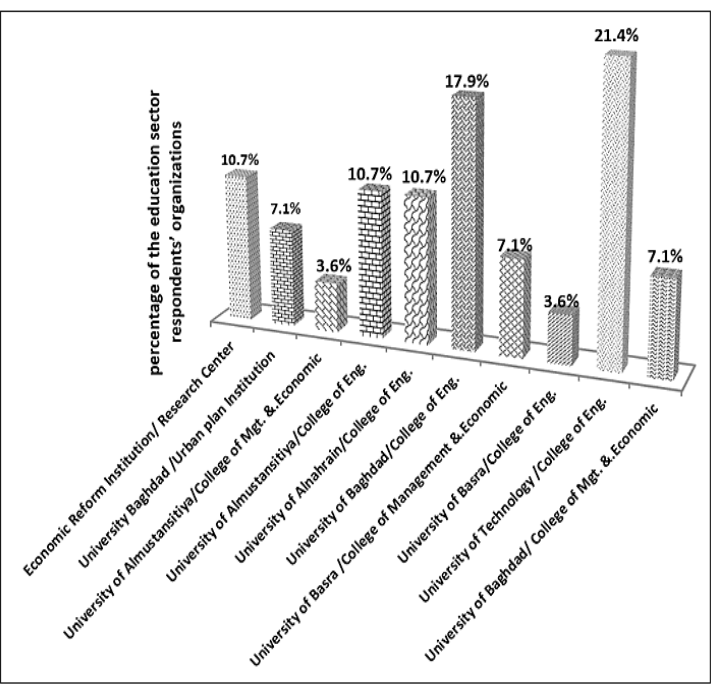

Fig. 3: Education sector respondents' organizations.

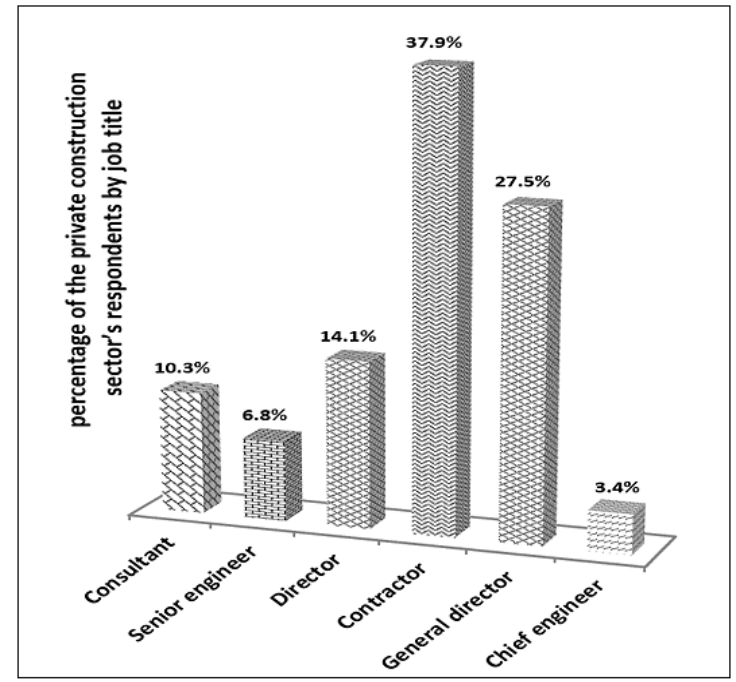

Fig. 5: The private sector respondents according to job title.

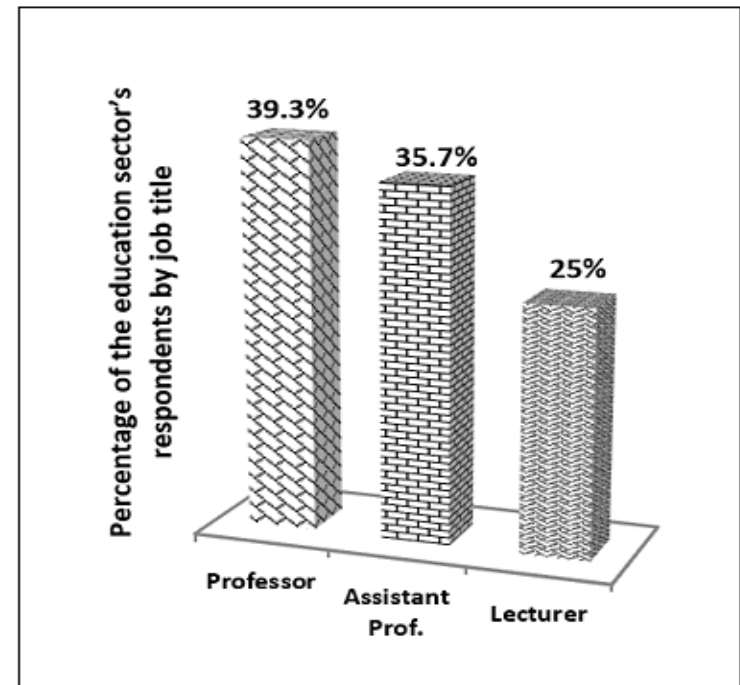

Fig. 6: The education sector respondents according job title. 


\subsubsection{Importance of CSFs for water supply projects (overall perceptions)}

The following formula was used to calculate the mean Score (MS) of the success factors to build up the relative significance of success factors:

Mean, $\bar{x}=\frac{\sum_{i=1}^{n}\left(f_{i} x_{i}\right)}{n}$,

where:

$x_{i}$ - variable score given by the respondents,

$f_{i}$ - response frequency,

$n$ - the responses total number of concerning that variable $(1 \leq \bar{x} \leq 6)$.

The statistical analysis (see Table 3) showed that the range of the CSFs mean values for the three sectors were 4.26 to 5.57. Overall, in descending order of importance, the top 5 most important success factors for water supply projects in Iraq were a stable political environment; sustainable construction legislation and regulation; effective risk management practices; well-organized and committed project teams; and government decisions through the project life cycle.

The five perceived factors that are to be of greatest importance to the public construction sector (group À) were stable political environment; sustainable construction legislation and regulation; project management efficiency and experience; effective risk management practices; and well organized and committed project team.

The success factor sorting as indicated by the private construction sector agrees with the standard way of thinking of being worried about the results of any government activities that may antagonistically influence venture income. It is, as a result, not surprising to see the five perceived factors that are to be of greatest importance to the private sector (group B) were stable political environment; effective risk management practices; sustainable construction legislation and regulation; well organized and committed project teams; and government decisions through the project life cycle.

On the other hand, the five factors based on the perceptions the education sector's experts (group C) were stable political environment; sustainable construction legislation and regulation; effective risk management practices, well organized and committed project team; and effective supply chain operations.

To determine the agreement between the experts, here we used Kendall's coefficient of concordance (W) which ranges from 0 to 1 . Siegel and Castellan [25] clarified Kendall's coefficient as:

$W=\frac{\sum_{i=1}^{n}\left(\bar{R}_{i}-\bar{R}\right)^{2}}{n\left(n^{2}-1\right) / 12}$,

where:

$n$ - the number of the factors being ranked,

$\bar{R}_{i}$ - the average ranks assigned to the ith factor,

$\overline{\mathrm{R}}$ - the average ranks assigned across all factors.

At a significance level of $1 \%$, the test was accomplished with a hypothesis that states there is no uniformity among the respondents in each group.

Thus, a p-value of less than $1 \%$ suggests a rejection of the null hypothesis. The Kendall's coefficient of concordance $W$ for $A ̀, B \&$ Ć groups was $0.108,0.129$, and 0.082 , respectively. At $0.0 \%$ significance level, the calculated values of the Ws were all statistically significant, which is below $1 \%$; thus, the null hypothesis were rejected for each group. This refers that there are consistency and significant agreement with respondents in each group in ranking the success factors for the water supply projects. Table 3 illustrates the relative significance of CSFs for the three groups of experts working in the construction (public and private) and education sectors. 
Table 3: Relative significance of CSF for water supply projects for construction (public and private) and education survey groups.

\begin{tabular}{|c|c|c|c|c|c|c|c|c|c|c|c|c|c|c|c|c|}
\hline \multirow{2}{*}{$\begin{array}{l}\text { Success } \\
\text { factors }\end{array}$} & \multicolumn{4}{|c|}{ Public sector (À) } & \multicolumn{4}{|c|}{ Private sector (ß) } & \multicolumn{4}{|c|}{ Education sector (Ć) } & \multicolumn{4}{|c|}{ Overall } \\
\hline & $\mathbf{N}$ & Mean & SD & Rank & $\mathbf{N}$ & Mean & SD & Rank & $\mathbf{N}$ & Mean & SD & Rank & $\mathbf{N}$ & Mean & SD & Rank \\
\hline $\mathrm{F} 1$ & 47 & 4.32 & 1.520 & 17 & 29 & 4.69 & 1.004 & 14 & 28 & 1... & 1.329 & 14 & 104 & 4.53 & 1.343 & 16 \\
\hline F2 & 48 & 5.35 & 0.911 & 2 & 29 & 5.34 & 0.614 & 3 & 28 & 5.39 & 0.629 & 2 & 105 & 5.36 & 0.761 & 2 \\
\hline F3 & 48 & 4.85 & 0.922 & 11 & 27 & 4.33 & 1.109 & 17 & 28 & 4.68 & 1.278 & 15 & 103 & 4.67 & 1.088 & 14 \\
\hline F4 & 48 & 3.85 & 1.856 & 18 & 29 & 4.55 & 1.152 & 16 & 28 & 4.64 & 1.254 & 16 & 105 & 4.26 & 1.569 & 18 \\
\hline F5 & 48 & 4.94 & 1.137 & 9 & 29 & 5.24 & 1.023 & 6 & 28 & 4.75 & 1.287 & 13 & 105 & 4.97 & 1.180 & 9 \\
\hline F6 & 48 & 5.21 & 0.824 & 4 & 29 & 5.41 & 0.733 & 2 & 28 & 5.32 & 0.723 & 3 & 105 & 5.30 & 0.771 & 3 \\
\hline F7 & 48 & 5.69 & 0.748 & 1 & 29 & 5.48 & 0.634 & 1 & 28 & 5.46 & 1.105 & 1 & 105 & 5.57 & 0.830 & 1 \\
\hline F8 & 48 & 4.85 & 1.082 & 11 & 29 & 5.14 & 0.789 & 8 & 28 & 4.86 & 1.145 & 9 & 105 & 4.93 & 1.012 & 10 \\
\hline F9 & 48 & 5.15 & 1.167 & 5 & 29 & 5.31 & 0.761 & 4 & 28 & 5.14 & 0.891 & 4 & 105 & 5.19 & 0.991 & 4 \\
\hline F10 & 46 & 5.13 & 1.108 & 6 & 28 & 5.14 & 0.858 & 7 & 28 & 4.79 & 1.031 & 11 & 102 & 5.04 & 1.024 & 6 \\
\hline F11 & 48 & 5.00 & 1.321 & 8 & 29 & 5.28 & 1.066 & 5 & 28 & 4.93 & 1.052 & 7 & 105 & 5.06 & 1.183 & 5 \\
\hline $\mathrm{F} 12$ & 47 & 4.87 & 1.279 & 10 & 28 & 4.82 & 1.124 & 13 & 28 & 3.96 & 1.453 & 18 & 103 & 4.61 & 1.337 & 15 \\
\hline $\mathrm{F} 13$ & 48 & 4.77 & 1.292 & 14 & 29 & 5.10 & 0.618 & 9 & 28 & 4.82 & 1.249 & 10 & 105 & 4.89 & 1.121 & 11 \\
\hline F14 & 48 & 5.10 & 0.928 & 7 & 29 & 4.86 & .789 & 11 & 28 & 4.96 & 1.170 & 5 & 105 & 5.00 & 0.961 & 8 \\
\hline F15 & 47 & 4.83 & 1.185 & 13 & 29 & 4.83 & 1.071 & 12 & 28 & 4.39 & 1.663 & 17 & 104 & 4.71 & 1.305 & 13 \\
\hline F16 & 48 & 4.46 & 1.288 & 16 & 29 & 4.31 & 1.561 & 18 & 28 & 4.79 & 1.031 & 12 & 105 & 4.50 & 1.309 & 17 \\
\hline F17 & 47 & 5.28 & 0.826 & 3 & 29 & 4.69 & 1.105 & 15 & 28 & 4.93 & 1.120 & 8 & 104 & 5.02 & 1.014 & 7 \\
\hline F18 & 48 & 4.48 & 1.584 & 15 & 29 & 4.97 & 0.944 & 10 & 28 & 4.96 & 1.036 & 6 & 105 & 4.74 & 1.308 & 12 \\
\hline
\end{tabular}

\subsubsection{Comparison of CSFs rankings among construction (public and private) and education sectors}

Table 3 shows that there are numerous contradictions reflected by the ranks and scorings of the three main groups regarding the CSFs. It was indicated that the ranking of factor F3 seems more significant in the group À (ranked 11) than group B (ranked 17) and group Ć (ranked 15). This implies that the both groups $B$ and $C$ were less worried about this factor, probably because they already have the technical skills for the project implementation. Factor F5 likewise obtains high score in group B (ranked 6) than group À (ranked 9) and group C (ranked 13). This shows that group B (private sector) realized the importance of this factor as it has a direct influence on the project time and cost.

In the same line, factor F6 in group B (ranked 2) was ranked lower in the group À (ranked 4) and group Ć (ranked 3). This means different risk opinions and reflects the extreme worries assumed by group $B$ (private sector) concerning the uncontrolled risks associated with the project. In addition, factor F10 was (ranked 11) in group C and it is higher in group À (ranked 6) and group B (ranked 7). An openness and constant communication between the clients/contractors is essential for successfully project implementation. Moreover, factor F11 was higher in group B (ranked 5) than group À (ranked 8) and group C (ranked 7). This explains the worried about the effects of any authority activities that might negatively influence project implementation.

Similarly, factor F14 was ranked higher in group Ć (rank 5) comparing to group À (ranked 7) to group $B$ (ranked 11). Then again, the positioning of factor (F16) was ranked lower in group C (ranked 18) comparing with group À (ranked 16) and group $B$ (ranked 12). This criterion implies that group $C$ (Education sector) more aware about the importance of factor 14 and 16 than other two groups, as the supply chain and project resources have a great effect on the project sustainability.

In contrast, factor F17 was ranked higher in group Ć (ranked 3) than group À (ranked 15) and group $B$ (ranked 8), which suggests different viewpoints. Generally, project cost can be overrun due to inefficient processes of the project management team; it can increase the risk of project delay.

Finally, factor F18 was ranked also higher in group Ć (ranked 6) than group À (ranked 15) and group B (rank 10). This means that group C (Education sector) realized the importance of this factor; this is primarily due to the fact that the end user of the water supply projects is the main beneficiary of the project. 
The differences among survey sample groups were clarified using the Kruskal Wallis $\mathrm{H}$ test, which is presented as follows [25]:

$H=\left[\frac{12}{N(N+1)} \times \sum \frac{T c^{2}}{n_{c}}\right]-3 \times(N+1)$,

$d f=n-1$,

where:

$d f$ - the freedom degree,

$N$ - the total participants number (combined),

$T_{c}$ - total rank (each group),

$n_{c}$ - the size (each group).

This test was used to evaluate the differences between two or more groups; the test was conducted at a predefined significance test value of $5 \%$. The null hypothesis is that there is no difference among the survey outputs of the three groups.

Table 4 confirms that there is a disagreement on factor F12. However, in spite of that Kruskal Wallis test explains the general distinction between groups, it does not show which explicit groups contrasted. Along these lines, Mann-Whitney U-test is performed. The Mann-Whitney U-test is a nonparametric test used to examine the level of agreement between two groups. [25] defined MannWhitney U-test as:

$U_{1}=n_{1} n_{2}+\frac{n_{1}\left(n_{1}+1\right)}{2}-R_{1}$,

$U_{2}=n_{1} n_{2}+\frac{n_{2}\left(n_{2}+1\right)}{2}-R_{2}$,

where:

$n_{1}$ - the size population for group one,

$n_{2}$ - the size population for group two,

$R_{1}$ - the ranks summation of group one,

$R_{2}$ - the ranks summation of group two.

At a predefined significance test value of $5 \%$, the test was preceded. The null hypothesis is that there is no difference between the surveys of the three groups. First, we compared group $A$ with $B$ followed by a comparison between group À with Ć. Finally group B with Ć. For passing up the type I error in the a certainty level, the $\alpha$ value would require adjusting. This is principally done by isolating $\alpha$ $(0.05)$ from the number of the necessary significance tests, which is here equals to three, the modified significance level for the Mann-Whitney three groups test was $\alpha=0.0167$.

Herein status, groups À to Ć have one significant difference in factor F12 $(0.005<0.0167)$. Given that that Mann-Whitney test has a similar outcome to the Kruskal Wallis test. Thusly, no further centrality tests should be performed. The Mann-Whitney $U$ test outcomes of pair-wise comparisons are shown in Table 5.

Table 4: Kruskal Wallis test for CSF among survey groups.

\begin{tabular}{|c|c|c|c|c|c|}
\hline \multirow{2}{*}{ CSF } & \multirow{2}{*}{ Chi-Square $(\boldsymbol{H}$ - value) } & \multirow{2}{*}{ Asymp. Sig. ( $\boldsymbol{p}$-value) } & \multirow{2}{*}{ Significant } & \multicolumn{2}{|c|}{ Effect size } \\
\cline { 4 - 6 } & & & $\mathbf{d}$ & Interpretation \\
\hline F1 & 1.459 & 0.482 & No & 1.42 & High effect \\
\hline F2 & 0.524 & 0.770 & No & 0.50 & Medium effect \\
\hline F3 & 3.753 & 0.153 & No & 3.68 & High effect \\
\hline F4 & 3.271 & 0.195 & No & 3.15 & High effect \\
\hline F5 & 2.444 & 0.295 & No & 2.35 & High effect \\
\hline F6 & 1.179 & 0.554 & No & 1.13 & High effect \\
\hline F7 & 4.135 & 0.127 & No & 3.98 & High effect \\
\hline F8 & 1.069 & 0.586 & No & 1.03 & High effect \\
\hline
\end{tabular}




\begin{tabular}{|c|c|c|c|c|c|}
\hline F9 & 0.512 & 0.774 & No & 0.49 & Medium effect \\
\hline F10 & 2.939 & 0.230 & No & 2.91 & High effect \\
\hline F11 & 2.091 & 0.352 & No & 2.01 & High effect \\
\hline F12 & 8.786 & 0.012 & Yes & 8.61 & ---- \\
\hline F13 & 0.234 & 0.890 & No & 0.22 & Low effect \\
\hline F14 & 2.009 & 0.366 & No & 1.93 & High effect \\
\hline F15 & 0.578 & 0.749 & No & 0.56 & Medium effect \\
\hline F16 & 1.229 & 0.541 & No & 1.18 & High effect \\
\hline F17 & 5.422 & 0.066 & No & 5.26 & High effect \\
\hline F18 & 1.237 & 0.539 & No & 1.19 & High effect \\
\hline
\end{tabular}

Table 5: Mann- Whitney U-test for CSF.

\begin{tabular}{|c|c|c|c|}
\hline \multirow{2}{*}{ Success factors } & \multicolumn{3}{|c|}{ Asymp. Sig. (2-tailed) / $\boldsymbol{p}$-value } \\
\cline { 2 - 4 } & $\dot{A}$ and B & $\dot{\text { A } \text { and Ć }}$ & $\boldsymbol{B}$ and Ć \\
\hline F1 & 0.473 & 0.256 & 0.610 \\
\hline F2 & 0.482 & 0.706 & 0.741 \\
\hline F3 & 0.048 & 0.766 & 0.203 \\
\hline F4 & 0.178 & 0.113 & 0.656 \\
\hline F5 & 0.225 & 0.660 & 0.131 \\
\hline F6 & 0.282 & 0.640 & 0.579 \\
\hline F7 & 0.040 & 0.413 & 0.325 \\
\hline F8 & 0.298 & 0.826 & 0.504 \\
\hline F9 & 0.982 & 0.525 & 0.529 \\
\hline F10 & 0.670 & 0.105 & 0.201 \\
\hline F11 & 0.399 & 0.462 & 0.141 \\
\hline F12 & 0.605 & 0.005 & 0.027 \\
\hline F13 & 0.650 & 0.862 & 0.727 \\
\hline F14 & 0.133 & 0.797 & 0.435 \\
\hline F15 & 0.920 & 0.419 & 0.660 \\
\hline F16 & 0.812 & 0.327 & 0.340 \\
\hline F17 & 0.019 & 0.236 & 0.397 \\
\hline F18 & 0.377 & 0.347 & 0.891 \\
\hline
\end{tabular}

\section{Conclusions}

Critical factors for success have been an area of interest in the literature of construction management for some time, and some research has provided evidence that such factors are sector specific. This led to different attempts to investigate the CSFs for different sectors. This paper identified eighteen CSFs for water supply projects in Iraq. These factors are important as they directly influence achieving project set objectives (time, cost, and quality). The mean values of response data from survey respondents were used to rank the water supply projects CSFs based on the perceptions of the construction (public and private) and education sectors in Iraq.

The top five important success factors for water supply projects in Iraq were a stable political environment; sustainable construction legislation and regulation; effective risk management practices; well-organized and committed project teams; and government decisions through the project life cycle.

The five perceived factors that are to be of greatest importance to the public sector (group A) were stable political environment; sustainable construction legislation and regulation; project management efficiency and experience; effective risk management practices; and well organized and committed project team.

The success factor sorting as indicated by the private sector agrees with the standard way of thinking of being worried about the results of any government activities that may antagonistically influence venture income. It is, as a result, not surprising to see the five perceived factors that are to 
be of greatest importance to the private sector (group B) were stable political environment; effective risk management practices; sustainable construction legislation and regulation; well organized and committed project teams; and government decisions through the project life cycle.

On the other hand, the five factors based on the perceptions the education sector's experts (group C) were stable political environment; sustainable construction legislation and regulation; effective risk management practices, well organized and committed project team; and effective supply chain operations.

It can be concluded from the outputs of this study that there is a dire need in Iraq to build up a stable political environment which can assist the expanding of the private construction sector's engagement to contribute towards the country's economy. In addition, the effective achievement of risk management tools and techniques plays a crucial role for the success of infrastructure projects. On the other hand,

Considering the CSFs for water supply projects can help construction contractors and stockholders to understand the root causes of project failure, the findings of this study can help stakeholders by focusing their attention to optimize the use of resources in the most effective way and obtain further insights and better likelihood of success. The outcomes of this investigation support the need for further research to enable a better understanding of CSFs for water supply projects, particularly for different partners including agents and potential customers.

\section{Acknowledgments}

This research did not receive any specific grant from funding agencies in the public, commercial, or not-for-profit sectors. The authors would like to thank the editor and anonymous reviewers for their comments that help improve the quality of this work.

\section{References}

[1] WIBOWO, A. - MOHAMED, S.: Risk criticality and allocation in privatized water supply projects in Indonesia. International Journal of Project Management, Vol. 28, 2010, pp. 504-513, doi:10.1016/j.jproman.2009.08.003.

[2] KAZDA, A. - SEDLÁČKOVÁ, A. N. - BRAČIĆ, M.: Expropriation and Airport Development. Civil and Environmental Engineering, Vol. 16, Iss. 2, 2020, pp. 282 - 288, doi: https://doi.org/10.2478/cee2020-0028.

[3] AMEYAW, E. E. - CHAN ALBERT, P. C.: Evaluating key risk factors for PPP water projects in Ghana: a Delphi study. Journal of Facilities Management, Vol. 13(2), 2015, pp. 133-155.

[4] PHUA, F. T. T. - ROWLINSON, S.: How important is cooperation to construction project success? A grounded empirical quantification. Engineering, Construction and Architectural Management, Vol. I (11), 2004, pp. 45-54.

[5] SINGH, MANINDER - SHARMA, S. K.: Critical Success Factors in Construction Projects. International Journal of Recent Technology and Engineering (IJRTE), Vol. 8(5), 2020.

[6] AGARI, M. - KHEYRODDIN, A. - NADERPOUR, H.: Evaluation of Project Critical Success Factors for Key Construction Players and Objectives. International Journal of Engineering (IJE), Vol. 31(2), 2018, p. 228-240, doi: 10.5829/ije.2018.31.02b.06.

[7] GUNDUZ, MURAT - YAHYA, AHMAD MOHAMMED, A.: Analysis of Project Success Factors in Construction Industry. Technological and Economic Development of Economy, Vol. 24(1), 2018, pp. 67-80, doi:10.3846/20294913.2015.1074129.

[8] PANCHAL, M.: Critical Success Factors for Water Supply Operation \& Maintenance. International Journal of Creative and Innovative Research in All Studies, Vol. 1(1), 2018.

[9] TAMGADGE, V. - SHINDE, D. K.: Analysis of Critical Success Factors for Construction Projects, 2018.

[10] MBITI, CHARLES, K.: Factors Influencing Effective Implementation of Mega Projects in Kenya: A Case of the Standard Gauge Railway Project. Imperial journal of interdisciplinary research (IJIR), Vol. 3(5), 2017.

[11] SILVA, S. K. - WAMAKULASURIYA, B. N. F. - ARACHCHIGE, B. J. H.: Critical Success Factors: En Route for Success of Construction Projects. International Journal of Business and Social Science, Vol. 7(3), 2016, pp. 27-37.

[12] OSORIO, P. C. F. - QUELHAS, O. L. G. - ZOTES, L. P. - SHIMODA, E. - FRANÇA, S.: Critical Success Factors in Project Management: An Exploratory Study of an Energy Company in Brazil, Global Journal of Management and Business Research: Administration and Management, 14 (10), 2014. 
[13] PAKSERESHT, A. - ASGARI, G.: Determining the critical success factors in construction projects: AHP approach. Interdisciplinary journal of contemporary research in business, Vol. 4(8), 2012, pp. 1-11.

[14] TABISH, S. Z. S. - JHA, K. N.: Identification and evaluation of success factors for public construction projects. Journal of Construction Management and Economics, Vol. 29(8), 2011, pp. 809-823.

[15] SAQIB, M. - FAROOQUI, R. U. - LODI, S. H.: Assessment of Critical Success Factors for Construction Projects in Pakistan. First International Conference on Construction in Developing Countries, Karachi, Pakistan, August 4-5, 2008.

[16] CENTRAL BANK OD IRAQ (CBI), Economic Annual Report, 2016, Baghdad, Iraq.

[17] AL-JUBOORI, OMAR A.: Conditions for Applying Public Private Partnership (PPP) in Iraq Infrastructure Projects Successfully. Ph.D. thesis, Department of Construction Management and Real Estate Development. Technical University of Munich-Germany, 2015, pp. 115-117.

[18] ZIMMERMANN, J. - ALJUBOORI, OMAR A.: The challenges of governing public private partnership in Iraq infrastructure projects. Creative Construction Conference, Budapest, Hungary, 2013, pp. 910-922.

[19] IRAQI MINISTRY OF PLANNING, Water Sector Report: Central Statistical Organization, Water Projects Statistics for the Year 2018, IRAQ, 2019.

[20] RESEARCH AND MARKET: Construction in Iraq: Key Trends and Opportunities to 2023. Online report. https://www.researchandmarkets.com/reports/4846333/construction-in-iraq-keytrends-and?utm_source=BW\&utm_medium $=$ PressRelease\&utm_code $=v k d n b v \& u t m \_c a m p a i g n=$ 1243574+-+Construction+in+Iraq+-+Key+Trends+and+Opportunities+to+2022\&utm_exec=chdo 54prd, 2019.

[21] PATANAKUL, P. - MILOSEVIC, D.: Standardized project management may increase development projects success. International Journal of Project Management, Vol. 23(3), 2005, pp. 181-192, doi.org/10.1016/j.jproman.2004.11.002.

[22] GUPTA AAYUSHI, G. - MAHESH, C. - AGRAWAL, R.: Identification and ranking of Critical Success Factors for BOT Projects in India. Journal of Management Research Review, Vol. 36(11), 2013, pp. 1040- 1060.

[23] NGUYEN, L. D. - OGUNLANA, S. O -; LAN, DO THI XUAN: A study on project Success factors in large construction projects in Vietnam. Engineering, Construction and Architectural Management, Vol. 11(6), 2004, pp. 404-413.

[24] OTHMAN, A. A. E.: Challenges of mega construction projects in developing countries. Organization, Technology and Management in construction, Vol. 5(1), 2013, pp. 730-746.

[25] SIEGEL, S. - CASTELLAN, N. J.: Nonparametric Statistics for the Behavioural Sciences. McGraw-Hill Inc.1988. 